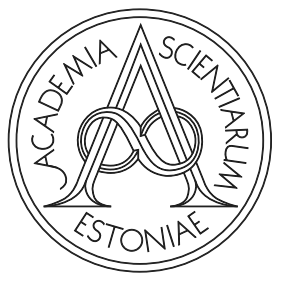

Proceedings of the Estonian Academy of Sciences, $2021,70,4,436-443$

https://doi.org/10.3176/proc.2021.4.10

Available online at www.eap.ee/proceedings

MANUFACTURING ENGINEERING

\title{
User-centred design in industrial collaborative automated systems
}

\author{
Simone Luca Pizzagalli*, Vladimir Kuts and Tauno Otto \\ Department of Mechanical and Industrial Engineering, Tallinn University of Technology, Ehitajate tee 5, 19086 Tallinn, Estonia
}

Received 15 June 2021, accepted 16 July 2021, available online 3 November 2021

(C) 2021 Authors. This is an Open Access article distributed under the terms and conditions of the Creative Commons AttributionNonCommercial 4.0 International License (http://creativecommons.org/licenses/by-nc/4.0/).

\begin{abstract}
Autonomous systems and collaborative robotics are part of the pillar technologies of the Industry 4.0 (I4.0) paradigm. These include advanced simulations, Digital Twins (DTs) and novel Human Machine Interfaces (HMIs). The increasing development of these technologies together with the higher requirements for customized production processes demands a closer collaboration between operators and automated systems. This leads to a redefinition of how human operators manage and interact with machines and how they are supported in this by adaptable interfaces, simulations and real-time data collection and analysis. New HumanRobot Collaboration (HRC) paradigms are paramount in a scenario where the boundaries between human and machine performed tasks are flexible and increasingly dematerialized. The redefinition of standards, design methods, programming interfaces and assessment techniques is central to facilitate these technological and production changes. The augmentation of human capabilities in the workplace insists on a definition of a framework of requirements that would integrate human, organizational and production needs in the same scenario and workflow. This research proposes a User-Centred Design (UCD) approach which is crucial in addressing the open challenges of HRC systems. Our work regards the DT as well as Augmented and Virtual Reality (AR/VR) technologies as central in this process by considering them key tools for the design, control, and assessment of modern collaborative industrial scenarios.
\end{abstract}

Key words: human-robot collaboration, user-centred design, Operator 4.0, digital twins, virtual reality.

\section{INTRODUCTION}

The Industry 4.0 (I4.0) revolution has systematized and clarified the future scenario for production processes towards the development of smart efficient and automated systems, including in its leading technologies big data and analytics, autonomous robots, simulation, system integration, industrial internet of things, cyber-physical systems, the cloud, additive manufacturing, and Augmented and Virtual Reality (AR/VR) [1]. Human-Robot Collaboration (HRC) is a crucial aspect in this scenario. Recent advancements in industrial automated systems and the need of production line flexibility, adaptability to market demand and customization are leading to a closer collaboration routine between human operators and robots

\footnotetext{
*Corresponding author, simone.pizzagalli@taltech.ee
}

in several industrial fields. The boundaries between the operator and machines are becoming less evident and tangible while the technologies involved in the modern production processes have a direct impact on the human workers, as they support and perfect human skills by sensing and perceptive technologies throughout the production lifecycle [2]. The newly born teaming paradigms are in need of natural, adaptive and intuitive Human Machine Interfaces (HMIs) that could support safety in HRC but also promote wellbeing and technology acceptance from the human operator perspective [3]. Recent studies show how Digital Twins (DTs) AR/VR interfaces can be valuable tools in the evaluation of safety [4] programming methods [5] and commissioning of HRC systems, while only a few studies attempt the combination of DT AR/VR technologies in a User-Centred Design (UCD) approach focusing on specific use cases. As much 
as industries adopting and implementing I4.0 technologies in their production lines are aware of the organization and human-related impacts and risks [6], no clear design and assessment methods are yet available or sufficient to provide a robust framework that would include human factors in design and decision-making strategies related to HRC. This research aims to address the HRC challenges by integrating the industrial collaborative robotic technologies into a user-centred design and evaluation framework. The main research question is whether DT AR/VR interfaces could be used as central tools for the development of modern user-centred robot collaboration systems, improving the efficiency and safety of interaction between operators and machines in the manufacturing field.

\section{HRC TRENDS IN I4.0}

Modern HRC systems combine the advantages of automation task repeatability and workload with specialized workers' soft skills and decision making [7]. Nevertheless, there are some requirements and open challenges in the development of efficient collaborative technologies including the design and implementation of intuitive interfaces. The latter would include different input modes, outputs and feedback, and robot centric issues such as safety, diversified programming approaches, design and control methods [8]. The future massive exploitation of collaborative robots in the manufacturing field will lead to many production processes and organizational adaptations within the industries and a series of human-centred concerns [9]. The impact of these technologies extends from the industrial environment to the operators with many different implications in each step of the production system. A large number of challenges are open to evaluation, assessment and integrated design solutions that would ease or accommodate operator monitoring technologies, stress level and workload assessment, technology acceptance, efficient reprogramming, ethics, privacy and handling of the data collected on the shop floor [10]. In this sense, the role of the operator itself and the type of interaction with the automated technology will be radically shifting from cooperation to an augmented and symbiotic paradigm. Romero et al. [11] describe this new worker as the Operator $4.0(\mathrm{O} 4.0)$, enhanced in its physical, sensorial and cognitive capabilities by the same technologies and systems involved in the fourth industrial revolution. This scenario requires the agents involved in this new production paradigm to be intelligent, perceptive and purposeful, aware of the context, autonomous, able to act, reflective, adaptable, learning, and conversational. Many of these characteristics are part of the human skills and competencies but seemingly missing in any industrial robotic system. Technologies that are already employed in advanced manufacturing support this evolution to a symbiotic enhancement of human operators' capabilities, being at the same time the main causes of ethical and human-related issues. IoT, advanced sensors, artificial intelligence, and data analysis promote smarter safety systems and learning approaches in robotic collaboration and programming by grounding their advanced capabilities precisely on human and environment-based data and behaviour analysis. Human operators are becoming a central matter of concern and the main driver of this transition. New methods are necessary to efficiently integrate the I4.0 technologies with the new O4.0 paradigm in a sustainable way. What is missing is a systematic approach that would allow the evaluation of all aspects involved in the HRC process and make DT AR/VR interfaces the main tool bridging humans and robots in a UCD approach.

\subsection{Collaboration levels, safety, and programming in HRC}

Levels of collaboration between the operator and automated systems, safety measures and programming methods, which are relying on advanced User Interface (UI), are among the most important aspects of HRC systems. Collaborative operations between the human partner and the robot can have different characterizations. In the study by Helms et al. [12] four types of levels are described: independent or parallel work, synchronized work, simultaneous work and assisted or collaborative scenarios. The latter is crucial in our proposed architecture and involves sharing workpiece, tools and workspace while performing the task at the same time. The relationship between safety, coexistence and collaboration in Human-Robot Interaction (HRI) is defined by De Luca et al. [13] as nested levels of the same framework describing interactions between humans and robots. While safety is considered the basic feature of industrial automated systems, coexistence and collaboration describe levels of interaction which involve sharing the same space and direct physical contact between the operator and the machine. Safety requirements for industrial collaborative automated systems are described in [14] and include four main different methods: Safety-Rated Monitored Stop, Hand Guiding, Speed and Separation Monitoring, and Power and Force Limiting. Each of these methods suggest a varied type of involvement and level of proximity which have various implications in task performance and programming operations. Different interaction methods must be supported by suitable context awareness approaches allowing automated systems to behave intelligently within the shop floor. These are mediated by artificial intelligence, industrial internet of things and 
advanced sensors which have different impact on the user, depending on the specific use case scenario and interaction modality. Programming of modern collaborative robots involves a variety of dedicated interfaces and methods. The most common techniques include: offline programming, where the operations are simulated on a computer and eventually exported to the robot system; online programming which involves traditional teach pendant interfaces; walk-through programming, a common method in the last generation of Cobots, in which the operator directly manipulates the robot while paths and trajectories are saved by the systems; Programming by Demonstration $(\mathrm{PbD})$, where the robotic systems learn the operations from actions performed by a human teacher. As much as not all robotic systems are suitable to be directly manipulated, the need for precise and reliable sensorized suites or motion tracking techniques seems to add complexity and costs to the adoption of efficient $\mathrm{PbD}$ methods. Moreover, world state information beyond the teacher-operator or the robot itself is not always properly mapped and described by the system [15]. AR/VR technologies offer a solution to several issues involved in programming procedures. The human operator is a predominant agent in all programming techniques by either manipulating the robot, demonstrating and teaching trajectories and operations, or as the end-user of complex programming software and UIs. Virtual reality interfaces offer a repeatable, scalable, controlled and safe test ground for innovative programming methods such as kinesthetic teaching [16] and user monitoring, and it can be applicable to older generations of robots.

\subsection{DT and $A R / V R$ interfaces in industrial automated system scenarios}

DTs are advanced representations of the real-world state and product or system components allowing for a realtime synchronized loop transmission of data between the digital and real entities. Beyond the first NASA applications and experimental works in this field and the well-known definition provided by Grieves [17], many other characterizations have been given to this technology [18]. The popularity of DT solutions both in the industrial and research field is constantly increasing with examples spanning from manufacturing applications, electric engine optimization [19] to building construction [20], aviation, and healthcare [21]. The flexibility of simulation-driven systems allows for applications supporting maintenance and production planning [22] to real-time data-driven models for product monitoring [23]. A few examples of a user-inclusive DT perspective in industrial systems can be found in [24-26]. Nevertheless, these approaches seems to be limited, both in terms of inclusion of the human factors in the loop, and in the design of accessible and intuitive interfaces aimed at data visualization and interactions with the digital counterpart [18]. AR/VR technologies can merge, on different levels and with different degrees of blending, the virtual and the real world [27], facilitating data visualization and creating a means of interaction between simulated systems and their real counterpart. A major advantage of AR/VR HMI for HRC is the inclusion of the end-user in the robotic cell's User Interface. By being an active agent in the automated system control UI, which in some cases coincides with the DT of the systems and factory floor environment itself, the operator becomes part of the twinning loop. This allows for direct data collection, task repeatability, user and environmental monitoring. Many recent studies have focused on experimental approaches to DT AR/VR interfaces with applications aimed at programming [28], control [29], design of collaborative industrial cells [30], and assessment of safety in HRC systems [31]. Only a limited number of examples address the potential of these technologies in becoming UCD and evaluation tools for advanced industrial systems and workstations [6,32]. Other experimental works, [4,33,34], attempt to adopt several user and system evaluation metrics for the assessment of immersive DT UI and interactions. These examples are limited to specific use cases and are not providing sufficiently comprehensive study protocols for HRI both from the technological system's and user's point of view. The shifting roles of automated technologies and human workforce in modern industry need a design and evaluation framework that can allow testing and validating interface efficiency for robot control, real-time system monitoring and synchronization, and impact on the user.

\section{UCD FOR HRC}

A different design approach is indispensable to efficiently integrate the new paradigms of $\mathrm{I} 4.0$ and $\mathrm{O} 4.0$ requirements into HRC. This framework should be able to integrate into the same design scope the above-mentioned challenges of collaborations methods, task organization, safety, programming, accessible UIs, production process organization and technology impact on the operator and factory organization. We propose that this integration should happen along the UCD iterative design process as defined in [35]. This design method places the end users at the centre and all along the design process involves different stakeholders and multidisciplinary resources in planning, testing, commissioning, and assessment of the system. Open multidisciplinary approaches can be found in design of complex intelligent systems such as autonomous vehicles [36]. Requirements should be drawn by analysing the target user group, the specific context of use, including organizational needs and 
objectives. Personal information, as well as demographics, knowledge of technical solutions, health-related issues, or body functionality, are at the base of the characterization of generic user models involved in the preliminary design process. Ethnographic research methods, including questionnaires, interviews, surveys, direct observations, can help in clarifying the needs and behaviours of the involved stakeholders at different levels of the context of use and design phases. Figure 1 shows how the new design approach allocates safety, collaboration modes, interfaces, task oriented and managerial requirements along the proposed iterative design and assessment process, matching the requirements and technologies which are typically involved in HRC with the UCD loop and specifications.

Our research proposal puts DT AR/VR interfaces at the centre of this design method constituting the O4.0 layer in the HRC structure and favouring interactions with the robotics systems. Figure 2 demonstrates the UCD

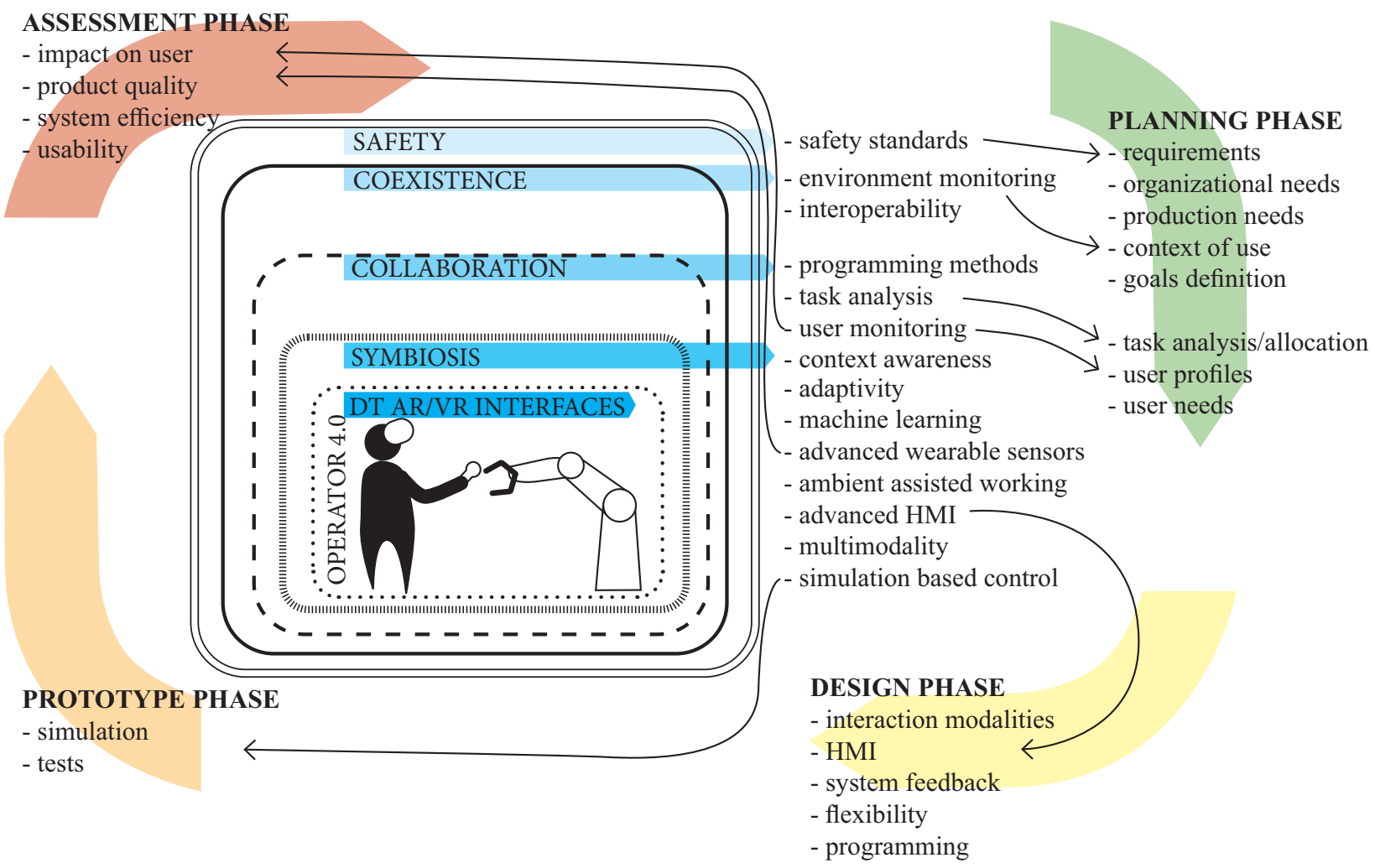

Fig. 1. Synergies between modern HRC systems and a user-centred iterative design process.



Fig. 2. Use case scenario of UCD approach in HRC making use of DT AR/VR interfaces. 
approach applied to the use case developed and discussed in [37]. This industrial robot use case shows how DT AR/VR technologies are able to include the operator in the HRC system interfaces.

Assessment of users' environmental and organizational aspects can be achieved by adopting real-time simulations and interaction technologies. These are based on industrial IoT, artificial intelligence, advanced sensors and data analysis having human, environment data and behaviour analysis as the main target, and smart, safe and easy-to-manage collaborative robotic systems as the main goal.

\section{USER-CENTRED DT AR/VR HRC SYSTEM ARCHITECTURE}

DT AR/VR technologies demonstrate high adaptability and scalability towards different features, programming methods and interfaces of industrial automated systems. Immersive simulations include the user in the DT loop and integrate environmental state information, allowing for safe reproducible and controlled experimental test grounds for the configuration and design of cyber-physical systems. For this reason, VR technologies could be adopted in existing ethnographic research methods [38]. The fast-paced advancements in hardware technologies favour the integration of motion tracking, eye-tracking, environmental or physiological sensors with VR headmounted displays and controllers. This enables many different interaction modalities, gestures, vocal or motion control with the digitalized counterpart of real machinery as well as the possibility of adopting advanced UI adaptivity and adaptability methods. Figure 3 shows the software integration model for DT AR/VR based collaborative automated system, structured along a UCD approach.

This model contributes to a highly immersive VR/AR training and control system. It provides an agent with higher-level involvement than customary training or control, and thus being more efficient in the HRC process. As already mentioned, there is a need for new metrics to assess and validate DT AR/VR interfaces for manufacturing systems that would respond to advancements in I4.0 technologies and new production requirements. The central point of the architecture and the proposed approach is that the metrics and methods for advanced collaborative systems should be developed in DT immersive interfaces first. VR interactive systems constitute the link between interaction and simulation by being at the same time the technology that allows humans to interact with the simulation and the HRC interface itself. In this scenario a further clarification is necessary on how one interacts within the virtual world, based on Human Computer Interaction (HCI) methodologies and a categorization of interaction metaphors and illusions allowed by the simulated world. It should also be clarified what the consequences of the interactions are on the DT of the robotic system in the simulation, based on DT technology enablers, requirements and performance; and how one interacts with the computer system and technology allowing for the simulation and interaction in the DT. The latter is also based on HCI standards but has proved to have both unprecedented built-in multimodal

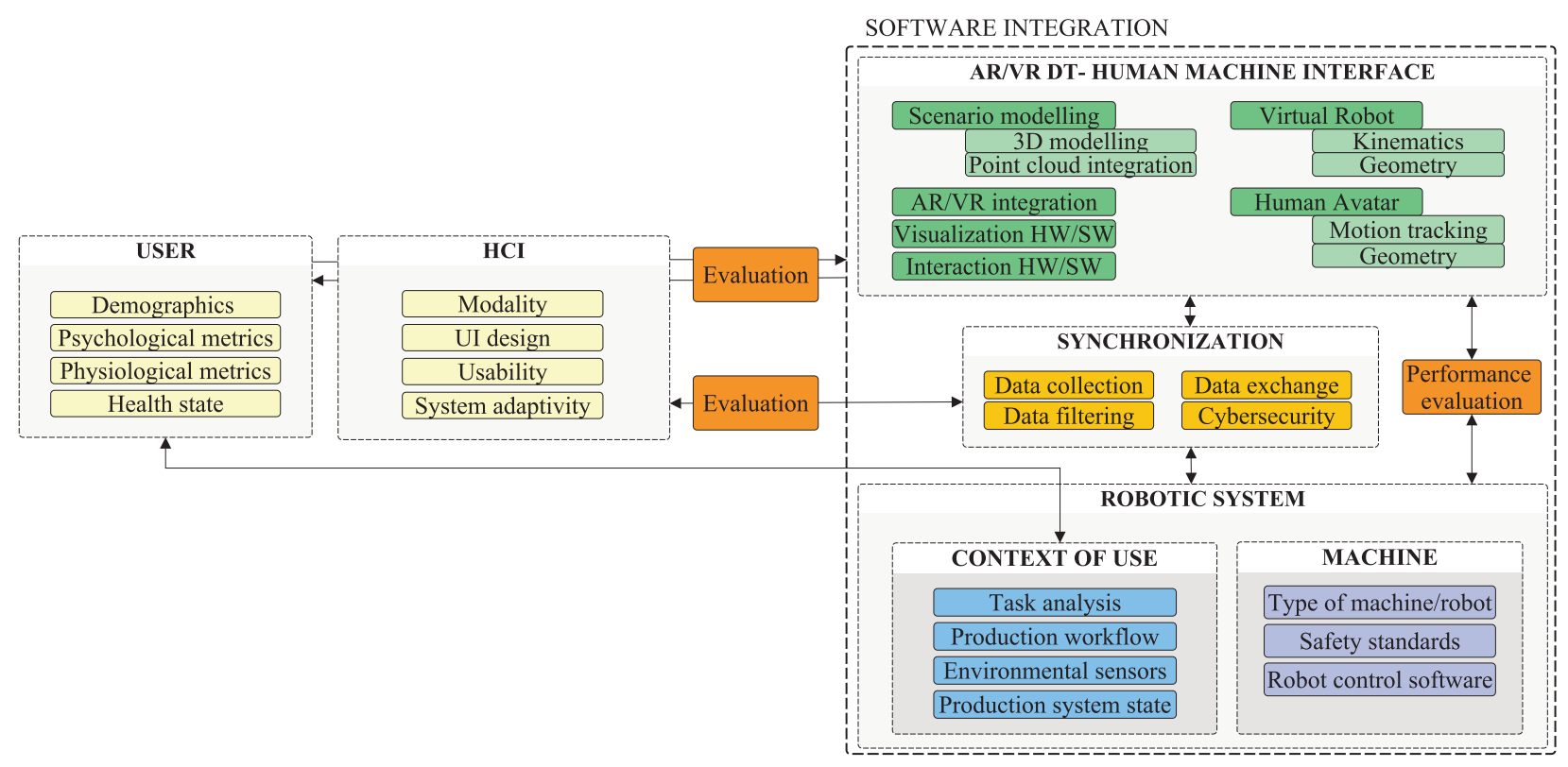

Fig. 3. Software integration architecture for UCD based HRC systems adopting DT AR/VR interfaces. 
potential and impact on the user. The proposed architecture responds to these requirements by efficiently allocating evaluation of DT system performance, HMI efficacy and usability, impact on the user and HRI assessment.

\section{CONCLUSIONS}

Holistic design solutions are necessary to respond to the impelling changes in industrial automated systems and the newly gained central position of the operators in collaborative scenarios. In this context human stakeholders, context of use, and organization of the production systems need to be reconsidered and optimized to match the new industrial requirements. UCD demonstrates how these elements can be organized in a design process that would iteratively plan, design and assess the newly adopted solutions while taking into account all the abovementioned critical elements. The central technologies in this process are DT AR/VR interfaces which have already demonstrated their scalability and efficiency in robotic system control and interaction, to support the evolution of O4.0 capabilities on the shop floor. As already mentioned, immersive visualization and interaction technologies include the user in the simulation and system interface supporting the evaluation of metrics and methods for HMI in HRC scenarios from UCD perspective. This new design and assessment solution would facilitate both the evaluation of psychological and physiological well-being ergonomics factors in HRI and the efficiency of advanced production processes and industrial cell deployment. Future research will give an in-depth overview of the state of the art of the DT AR/VR applications in the industrial field by comparing the type of use case scenarios, interaction methods, and assessment metrics. Based on the existing use case presented in Fig. 2, future experimental studies will try to assess the interaction of the human operator with each layer of the proposed architecture including the interaction with the robot, with the AR/VR technologies and hardware, and the DT simulation of the industrial system. Future user-centred studies will find shared evaluation metrics between the different interaction levels, the design solutions of which would allow best performance and low impact on the user and on how AR/VR are best integrated with the DT loop in HRC scenarios. Interrelations between the elements of the proposed architecture need to be evaluated in light of the defined assessment parameters. Customization and visualization of these connections might also be taken into consideration for a better fit into different use case scenarios. From the technical point of view cybersecurity for user and environmental data collection and handling will have to be addressed. Connectivity and synchronization methods between the physical and virtual systems will be further explored and extended to include virtual distributed infrastructure for control and interaction with different machinery that will offer an experimental test ground and modular virtual interface for both system integrators and researchers.

\section{ACKNOWLEDGEMENTS}

This work was supported by the Estonian Research Council grant TT2 "Smart Industry Centre (SmartIC)". The publication costs of this article were covered by the Estonian Academy of Sciences and Tallinn University of Technology.

\section{REFERENCES}

1. Vaidya, S., Ambad, P. and Bhosle, S. Industry 4.0 - a glimpse. Procedia Manuf., 2018, 20, 233-238. https://doi.org/ 10.1016/j.promfg.2018.02.034

2. Romero, D., Bernus, P., Noran, O., Stahre, J. and Fast-Berglund, Å. The Operator 4.0: human cyber-physical systems \& adaptive automation towards human-automation symbiosis work systems. IFIP Adv. Inf. Commun. Technol., 2016, 488, 677-686. https://doi.org/10.1007/978-3-31951133-7 80

3. Berg, J. and Lu, S. Review of interfaces for industrial human-robot interaction. Curr. Rob. Rep., 2020, 1, 27-34. https://doi.org/10.1007/s43154-020-00005-6

4. Oyekan, J. O., Hutabarat, W., Tiwari, A., Grech, R., Aung, M. H., Mariani, M. P. et al. The effectiveness of virtual environments in developing collaborative strategies between industrial robots and humans. Rob. Comput. Integr. Manuf., 2019, 55(A), 41-54. https://doi.org/10.1016/j.rcim.2018.07.006

5. Burghardt, A., Szybicki, D., Gierlak, P., Kurc, K., Pietruś, P. and Cygan, R. Programming of industrial robots using virtual reality and digital twins. Appl. Sci., 2020, 10(2), 486. https://doi.org/10.3390/app10020486

6. Longo, F., Padovano, A. and Umbrello, S. Value-oriented and ethical technology engineering in Industry 5.0: A human-centric perspective for the design of the factory of the future. Appl. Sci., 2020, 10(12), 4182. https://doi.org/ 10.3390/APP10124182

7. Nahavandi, S. Industry 5.0 - a human-centric solution. Sustainability, 2019, 11(16), 4371. https://doi.org/10.3390/ su11164371

8. Villani, V., Pini, F., Leali, F. and Secchi, C. Survey on human-robot collaboration in industrial settings: Safety, intuitive interfaces and applications. Mechatronics, 2018, 55, 248-266. https://doi.org/10.1016/j.mechatronics.2018.02.009

9. Demir, K. A., Döven, G. and Sezen, B. Industry 5.0 and human-robot co-working. Procedia Comput. Sci., 2019, 158, 688-695. https://doi.org/10.1016/j.procs.2019.09.104

10. Bagdasarov, Z., Martin, A. A. and Buckley, M. R. Working with robots: Organizational considerations. Organ. Dyn., 
2020, 49(2), 100679. https://doi.org/10.1016/j.orgdyn.2018. 09.002

11. Romero, D., Stahre, J. and Taisch, M. The Operator 4.0: Towards socially sustainable factories of the future. Comput. Ind. Eng., 2020, 139, 106128. https://doi.org/10.1016/j.cie. 2019.106128

12. Helms, E., Schraft, R. D. and Hägele, M. Rob@work: Robot assistant in industrial environments. In Proceedings of the 11th IEEE International Workshop on Robot and Human Interactive Communication, Berlin, Germany, September 27 , 2002. IEEE, 399-404. https://doi.org/10.1109/ROMAN. 2002.1045655

13. De Luca, A. and Flacco, F. Integrated control for pHRI: Collision avoidance, detection, reaction and collaboration. In Proceedings of the 2012 4th IEEE RAS \& EMBS International Conference on Biomedical Robotics and Biomechatronics (BioRob), Rome, Italy, June 24-27, 2012. IEEE, 288-295. https://doi.org/10.1109/BioRob.2012.6290917

14. ISO/TS 15066:2016. Robots and robotic devices - Collaborative robots. International Organization for Standardization, Geneva, 2016. https://www.iso.org/standard/62996.html

15. Argall, B. D., Chernova, S., Veloso, M. and Browning, B. A survey of robot learning from demonstration. Rob. Auton. Syst., 2009, 57(5), 469-483. https://doi.org/10.1016/j.robot. 2008.10.024

16. DelPreto, J., Lipton, J. I., Sanneman, L., Fay, A. J., Fourie, C., Choi, C. and Rus, D. Helping robots learn: a humanrobot master-apprentice model using demonstrations via virtual reality teleoperation. In Proceedings of the 2020 IEEE International Conference on Robotics and Automation (ICRA), Paris, France, May 31-August 31, 2020. IEEE, 10226-10233. https://doi.org/10.1109/ICRA40945.2020.9196754

17. Grieves, M. Digital Twin: manufacturing excellence through virtual factory replication. White Paper, 2014. https://www.researchgate.net/publication/275211047_Digita 1_Twin_Manufacturing_Excellence_through_Virtual_Factor y_Replication

18. Barricelli, B. R., Casiraghi, E. and Fogli, D. A survey on Digital Twin: definitions, characteristics, applications, and design implications. IEEE Access, 2019, 7, 167653-167671. https://doi.org/10.1109/ACCESS.2019.2953499

19. Rassõlkin, A., Vaimann, T., Kallaste, A. and Kuts, V. Digital twin for propulsion drive of autonomous electric vehicle. In Proceedings of the 2019 IEEE 60th International Scientific Conference on Power and Electrical Engineering of Riga Technical University (RTUCON), Riga, Latvia, October 7-9, 2019. IEEE, 2020, 1-4. https://doi.org/10.1109/RTUCON 48111.2019.8982326

20. Khajavi, S. H., Motlagh, N. H., Jaribion, A., Werner, L. C. and Holmström, J. Digital Twin: vision, benefits, boundaries, and creation for buildings. IEEE Access, 2019, 7, 147406147419. https://doi.org/10.1109/ACCESS.2019.2946515

21. Bruynseels, K., Santoni de Sio, F. and van den Hoven, J. Digital Twins in health care: ethical implications of an emerging engineering paradigm. Front. Genet., 2018, 9, 31. https://doi.org/10.3389/fgene.2018.00031

22. Terkaj, W., Tolio, T. and Urgo, M. A virtual factory approach for in situ simulation to support production and maintenance planning. CIRP Ann., 2015, 64(1), 451-454. https://doi.org/10.1016/j.cirp.2015.04.121
23. Tšukrejev, P., Kruuser, K. and Karjust, K. Production monitoring system development for manufacturing processes of photovoltaic modules. Proc. Est. Acad. Sci., 2019, 68(4), 401-406. https://doi.org/10.3176/proc.2019.4.09

24. Graessler, I. and Poehler, A. Integration of a digital twin as human representation in a scheduling procedure of a cyberphysical production system. In Proceedings of the 2017 IEEE International Conference on Industrial Engineering and Engineering Management (IEEM), Singapore, December 10-13, 2017. IEEE, 2018, 289-293. https://doi.org/10.1109/ IEEM.2017.8289898

25. Wang, Q., Jiao, W., Wang P. and Zhang, Y. Digital Twin for human-robot interactive welding and welder behavior analysis. IEEE/CAA J. Autom. Sin., 2021, 8(2), 334-343. https://doi.org/10.1109/JAS.2020.1003518

26. Buldakova, T. I. and Suyatinov, S. I. Hierarchy of human operator models for Digital Twin. In Proceedings of the International Russian Automation Conference (RusAutoCon), Sochi, Russia, September 8-14, 2019. IEEE, 1-5. https://doi.org/ 10.1109/RUSAUTOCON.2019.8867602

27. Milgram, P., Drascic, D., Grodski, J. and Restogi, A. Merging real and virtual worlds. Proc. IMAGINA'95, 1995.

28. Kuts, V., Sarkans, M., Otto, T., Tähemaa, T. and Bondarenko, Y. Digital Twin: concept of hybrid programming for industrial robots - use case. In Proceedings of the ASME 2019 International Mechanical Engineering Congress and ExpositionAdvanced Manufacturing. 2020, 2B. https://doi.org/10.1115/ IMECE2019-10583

29. Horváth, G. and Erdős, G. Gesture control of cyber physical systems. Procedia CIRP, 2017, 63, 184-188. https://doi.org/10.1016/j.procir.2017.03.312

30. Pérez, L., Rodríguez-Jiménez, S., Rodríguez, N., Usamentiaga, R. and García, D. F. Digital Twin and virtual reality based methodology for multi-robot manufacturing cell commissioning. Appl. Sci., 2020, 10(10), 3633. https://doi.org/10.3390/app10103633

31. Vosniakos, G. C., Ouillon, L. and Matsas, E. Exploration of two safety strategies in human-robot collaborative manufacturing using Virtual Reality. Procedia Manuf., 2019, 38, 524-531. https://doi.org/10.1016/j.promfg.2020.01.066

32. Peruzzini, M., Grandi, F. and Pellicciari, M. Exploring the potential of Operator 4.0 interface and monitoring. Comput. Ind. Eng., 2020, 139, 105600. https://doi.org/ 10.1016/j.cie.2018.12.047

33. Concannon, D., Flynn, R. and Murray, N. A quality of experience evaluation system and research challenges for networked virtual reality-based teleoperation applications. In Proceedings of the 11th ACM Workshop on Immersive Mixed and Virtual Environment Systems - MMVE. 2019, 10-12. https://doi.org/10.1145/3304113.3326119

34. Whitney, D., Rosen, E., Phillips, E., Konidaris, G. and Tellex, S. Comparing robot grasping teleoperation across desktop and virtual reality with ROS reality. In Robotics Research. Springer Proceedings in Advanced Robotics. Springer, Cham, 2020, 10, 335-350. https://doi.org/10.1007/ 978-3-030-28619-4_28

35. ISO 9241-210:2019. Ergonomics of Human-System Interaction - Human-Centred Design for Interactive Systems. International Organization for Standardization, Geneva, 2010. https://www.iso.org/standard/77520.html 
36. Sell, R., Leier, M., Rassõlkin, A. and Ernits, J.-P. Self-driving car ISEAUTO for research and education. In Proceedings of the 2018 19th International Conference on Research and Education in Mechatronics, Delft, Netherlands, June 7-8, 2018. IEEE, 111-116. https://doi.org/10.1109/REM.2018. 8421793

37. Kuts, V., Otto, T., Tähemaa, T. and Bondarenko, Y. Digital twin based synchronised control and simulation of the industrial robotic cell using virtual reality. J. Mach. Eng., 2019, 19(1), 128-144. https://doi.org/10.5604/01.3001.00 13.0464

38. Rebelo, F., Noriega, P., Duarte, E. and Soares, M. Using virtual reality to assess user experience. Hum. Factors, 2012, 54(6), 964-982. https://doi.org/10.1177/0018720812 465006

\section{Kasutajakeskne disain tööstuslikes koostööautomaatsüsteemides}

\section{Simone Luca Pizzagalli, Vladimir Kuts ja Tauno Otto}

Autonoomsed süsteemid ja koostöörobootika on Tööstus 4.0 paradigma ühed olulisemad tugitehnoloogiad. Siia hulka kuuluvad täiustatud simulatsioonid, digitaalsed kaksikud ja uudsed inim-masinliidesed. Nende tehnoloogiate areng koos kohandatud tootmisprotsessidele esitatavate kõrgemate nõuetega eeldab tihedamat koostööd operaatorite ja automatiseeritud süsteemide vahel. Seetõttu tuleb ümber defineerida kogu senine töökorraldus: kuidas inimoperaatorid masinaid haldavad ja nendega suhtlevad ning kuidas neid selleks kohandatavad liidesed, simulatsioonid ja reaalajas andmete kogumine ning analüüs toetavad. Uued inimese ja roboti koostöö paradigmad on ülimalt olulised stsenaariumis, kus piirid inimeste ja masinate sooritatavate ülesannete vahel on paindlikud ja hägusad. Standardite, disainimeetodite, programmeerimisliideste ja hindamismeetodite uuesti määratlemine on nende tehnoloogiliste ja tootmismuudatuste hõlbustamisel kesksel kohal. Inimvõimekuse suurendamine töökohal tingib vajaduse määratleda nõuete raamistik, mis integreeriks inim-, organisatsiooni- ja tootmisvajadused samasse stsenaariumi ja töövoogu. Antud uurimus pakub lahendusena välja kasutajakeskse disaini eelistamise, mis on inimese ja roboti koostöösüsteemidele avatud väljakutsete lahendamisel ülioluline. Meie metoodika peab digitaalseid kaksikuid ning liit- ja virtuaalreaalsuse tehnoloogiaid peamisteks tööriistadeks nüüdisaegsete koostööstsenaariumide kujundamisel, juhtimisel ja hindamisel. 